\title{
EVALUATING GLACIER DYNAMICS USING TEMPORAL REMOTE SENSING IMAGES: A CASE STUDY OF HUNZA VALLEY, NORTHERN PAKISTAN
}

\author{
M. Shafique ${ }^{1,2 *}$, B. Faiz ${ }^{1}$, A. Bacha ${ }^{1}$ \\ ${ }^{1}$ National Centre of Excellence in Geology, University of Peshawar, Pakistan - shafique@ upesh.edu.pk, baberfaiz89@gmail.com , \\ mian.alamsher@gmail.com \\ 2 Faculty of Environmental Design, King Abdulaziz University, Kingdom of Saudi Arabia
}

KEY WORDS: Glaciers, Karakorum anomaly, climate change, remote sensing, northern Pakistan

\begin{abstract}
Glaciers are the major source of water for drainage network. Northern Pakistan is hosting some of the largest and longest glaciers. Studies evaluating the temporal dynamics of glaciers in Pakistan shows contradictory results of retreat, stable of advancing behavior. Aim of the present study is to evaluate the temporal dynamics in three glaciers in northern Pakistan, using Landsat satellite images. The Landsat images for the years of 1977, 1999, 2001, 2007, 2009 and 2014 shows retreat in selected Hispar, Birpu and Bualtar glaciers. To evaluate the impact of weather indicators of the glaciers dynamics, the temporal glaciers inventories were compared with the rainfall and temperature for the corresponding years. This study should assist to understand the glaciers dynamics and future climate of the region.
\end{abstract}

Keywords: Glaciers, northern Pakistan, remote sensing, climate change, Karakorum Anomaly

\section{INTRODUCTION}

Glaciers in mountain areas are the major source of water for downstream drainage network and irrigation for agriculture. However, due to the climate change phenomenon and global warming, there is an increase of $0.85^{\circ} \mathrm{C}$ since 1980 in average global temperatures, which are expected to reach to $3.7^{\circ} \mathrm{C}$ by the end of the 21st century (IPCC, 2013). This increased in global temperature leads to faster glaciers melting and resulted in sea level rise, flooding, varying water supply, Glacial Lake Outburst Floods (GLOF) and erosion (Bajracharya et al., 2014; Durán-Alarcón et al., 2015; López-Moreno et al., 2014; Schauwecker et al., 2014). Glaciers in the Karakorum mountain ranges in northern Pakistan, shows spatially different temporal trends of retreat, stable or advance, which make it hard to forecast the climate for the region (Scherler et al., 2011a).

For regional scale studies, space-borne satellite images are effectively and efficiently utilized to quantify, monitor and describe the glaciers area, spatial extent, mass balance and associated hazards and impacts (Ashraf et al., 2012; Dehecq et al., 2015; Paul et al., 2004a; Racoviteanu et al., 2008; Scherler et al., 2011b; Scherler et al., 2008). For local scale studies, airborne images acquired through aerial surveys and Unmanned Aerial Vehicles (UAVs) are often utilized for detailed characterization and spatial distribution of glaciers (Kraaijenbrink et al., 2016b). Fine resolution satellite images are effective for detailed characterization of glaciers, however, their high costs limit their use for regional scale studies (Burns and Nolin, 2014; Racoviteanu and Williams, 2012). Landsat satellite images, given their easy accessibility, free availability, long archive and with global coverage are effectively utilized for assessing glaciers (Bhardwaj et al., 2015; Racoviteanu et al., 2008). Range of image classification and interpretation techniques are utilized for assessing glaciers and associated features, including visual based image interpretation, digital image classification, object based image analysis (OBIA), manual digitization and band ration such as
Normalized Difference Snow Index (NDSI) (Bajracharya et al., 2014; Bolch et al., 2010; Hall et al., 1995; Kraaijenbrink et al., 2016a; Sibandze et al., 2014). The debris covered glaciers poses challenges for digital image classification techniques (Racoviteanu et al., 2008). Manual digitization of images using the visual image interpretation, supported with field information, are effectively used in region with presence of both the clean and debris covered glaciers. (Paul et al., 2013).

Mountain ranges in northern Pakistan, including the Karakorum, Himalaya and Hindukush are hosting some of the world's largest and longest mid-latitude glaciers (Williams et al., 2010). Some of the large glaciers in the region include the Baltoro, Biafo, Siachen and Hispar glaciers. Temporal study of the Burche and Siachen glaciers shows retreat of 0.11 and $0.05 \mathrm{Km}^{2}$, respectively between the 2000 and 2014 (Muhammad and Tian, 2016). According to Rankl et al. (2014), 969 out of 1219 glaciers in the area shows stable trends in the period of 1976-2012. In the high elevation, 13 glaciers shows advancing trends (Tahir et al., 2011). Bocchiola and Diolaiuti (2013) and Hewitt (2005) observed that the glaciers in the central and eastern Himalayas, Hindu-Kush and Karakoram, shows different trends of advance, stable or retreat, which is known as "Karakoram Anomaly". This anomalous behavior can be attributed to supra glacier debris cover and lack of mass balance data (Gibson et al., 2017; Scherler et al., 2011a). Aim of this study is to evaluate the temporal dynamics of glaciers using the Landsat images and weather data, in northern Pakistan.

\subsection{Study area}

The study area is located district Hunza Nagar in northern Pakistan (Figure. 1). Elevation of the area ranges from 3000 7900 meters (ASL). Climate of the area is moderate with average rainfall of $136.2 \mathrm{~mm} /$ year and average minimum and maximum temperatures of $16{ }^{\circ} \mathrm{C}$ and $35.9{ }^{\circ} \mathrm{C}$, respectively (Qureshi et al., 2017). 


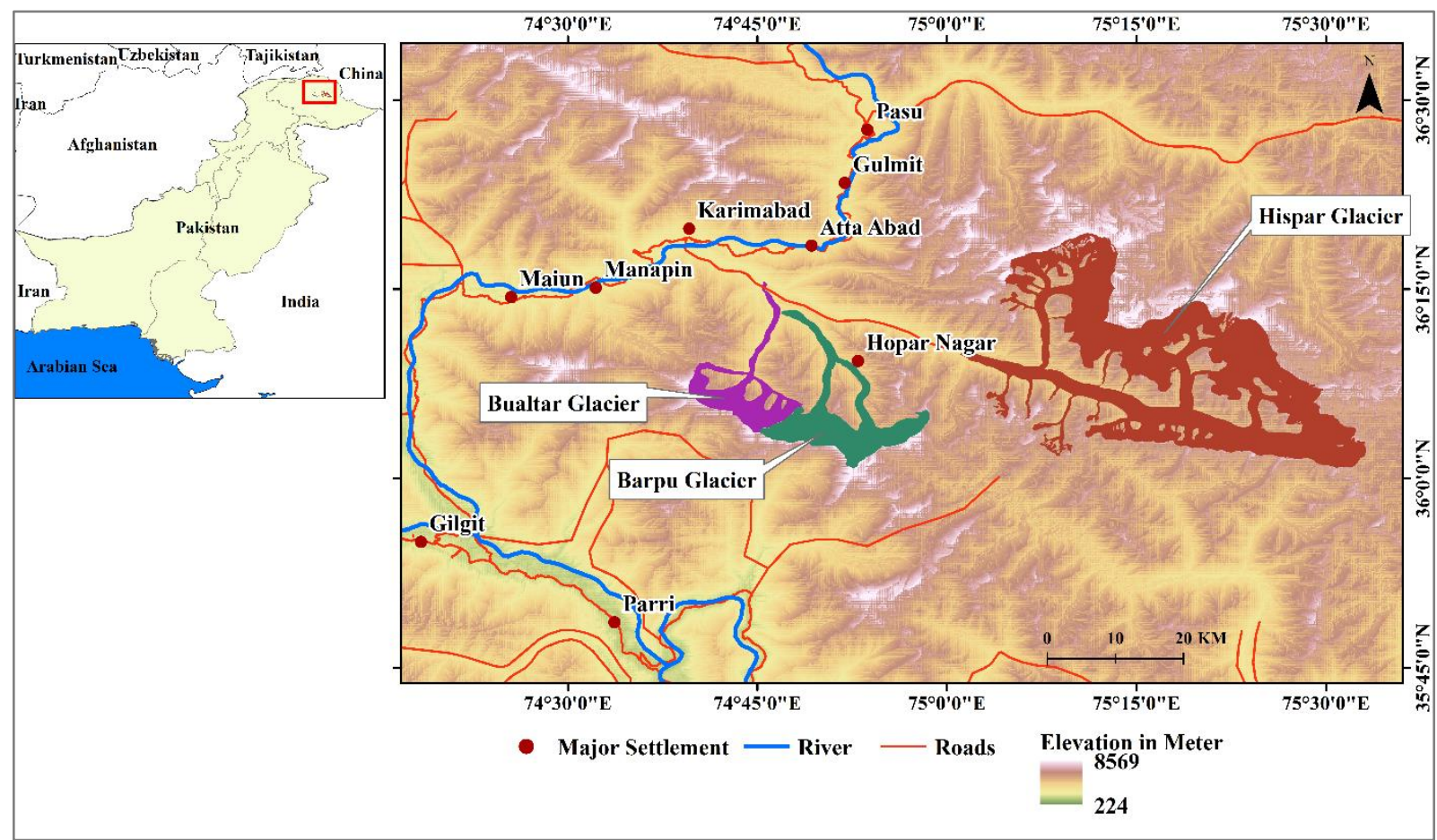

Figure 1: Location map of the study area

In the area, glaciers are mostly valley glaciers feeding the Hunza Nagar River and irrigation water for agriculture in the surrounding areas. For this study, the selected glaciers include Hispar, Barpu and Baultar (Figure 1).

\subsection{Material and Methods:}

To assess the temporal changes in the selected glaciers, Landsat images for the years 1977, 1999, 2001,2007, 2009 and 2014 were collected. The images were selected considering the minimum cloud cover and consistent months of acquisition. The SRTM DEM was utilized to orthorectify the acquired images. Normalized Difference Snow Index (NDSI) is effectively applied to the satellite images to extract the snow cover (Burns and Nolin, 2014). To map the snow cover, NDSI threshold value is selected based on the reflectance characteristics of snow. In this study, we have used NDSI value of $\geq 0.6$ and terrain slope of $>12^{\circ}$ to demarcate the glaciers boundary (Bajracharya et al., 2014). The developed glaciers boundaries are subsequently rectified using the manual editing and field observation. The glacier area derived from the acquired inventories were analyzed to assess the trends in the selected glaciers.

The weather record of the area was acquired from the Pakistan Meteorological Department for the corresponding years of collected satellite images. The influence of the precipitation and temperature on the glacier dynamics was evaluated by comparing the record with glacier inventories.

\section{RESULTS}

The selected glaciers i.e. Hispar, Barpu and Baultar shows retreating trends between 1977 and 2014 (Figure 2 and Table 1). However, glaciers melting rate is varying among the selected glaciers. The clean Bualtar glacier shows highest retreat of $49 \%$ during the selected period of 1977-2014 compared to $20.89 \%$ in the Barpu and $26.33 \%$ in the Hispar Glaciers. The partly debris covered Hispar and Barpu glaciers shows relatively less retreat during the selected period. The variation in the snout of the selected glaciers is shown in the Figure 3.

Derived results from the study are consistent with the alike studies in other parts of the world such as Alaska (Larsen et al., 2007); Canada (Bolch et al., 2010); Alps (Paul et al., 2004b); and Himalaya (Bajracharya et al., 2014). Difference in the glaciers melting rate in the region are mainly credited to the presence of supra-glacial debris cover ( $\mathrm{Li}$ and Lin, 2017; Scherler et al., 2011a). It is observed that the debris free glaciers are melting at faster rate than the debris covered glaciers. The melting of glaciers in the area can also be attributed to the rise in temperature of $0.76{ }^{\circ} \mathrm{C}$ in the last 4 decades in northern Pakistan (Chaudhry et al., 2009). The region has also experienced fall in precipitation/snowfall also contributing to retreat of glaciers (Yao et al., 2012).

Table 1:Glacier dynamics in the selected glaciers

\begin{tabular}{|c|c|c|c|c|c|c|c|c|}
\hline \multirow{2}{*}{ Glaciers } & \multicolumn{8}{|c|}{ Glacier area in in the $\mathrm{Km}^{2}$ in the selected years } \\
\hline & 1977 & 1999 & 2001 & 2007 & 2009 & 2014 & \begin{tabular}{|l} 
Loss \\
from \\
1977 \\
to \\
2014
\end{tabular} & $\begin{array}{c}\text { Loss } \\
1977- \\
2014 \text { in } \\
\%\end{array}$ \\
\hline Hispar & 540.4 & 471.6 & 451.7 & 438 & 430.6 & 398.1 & 142.3 & 26.3 \\
\hline Barpu & 105.2 & 98.01 & 93.5 & 89 & 86.61 & 83.2 & 21.9 & 20.9 \\
\hline Bualtar & 75.03 & 69.21 & 61.34 & 53.3 & 47.51 & 38.1 & 36.9 & 49.2 \\
\hline
\end{tabular}



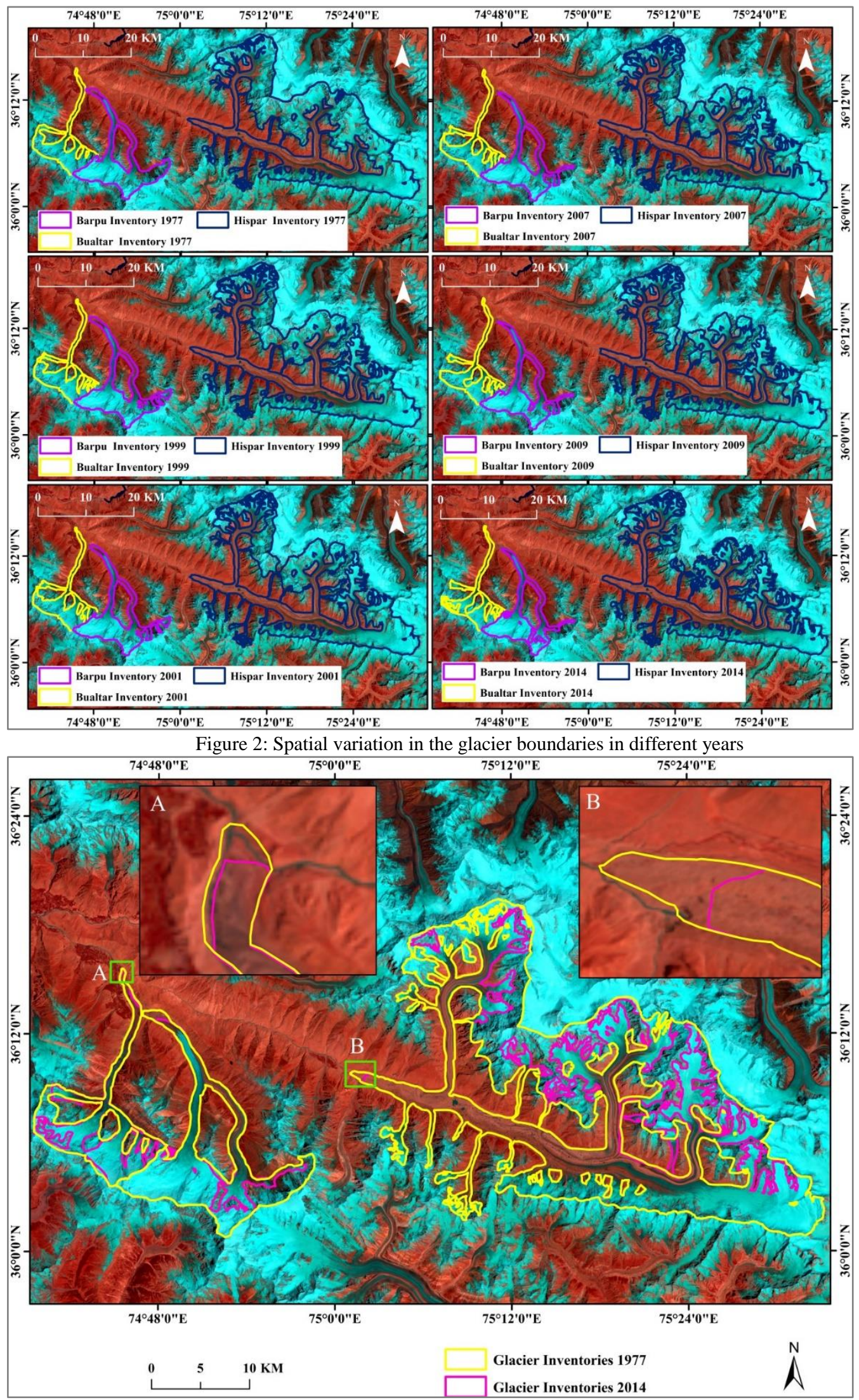

Figure 3: Variation of glaciers snout during different years 
To assess the impact of climatic variables including precipitation and temperature on the glaciers changes, the developed temporal glacier inventories were compared with the precipitation and temperature of the matching year (Figure 4)

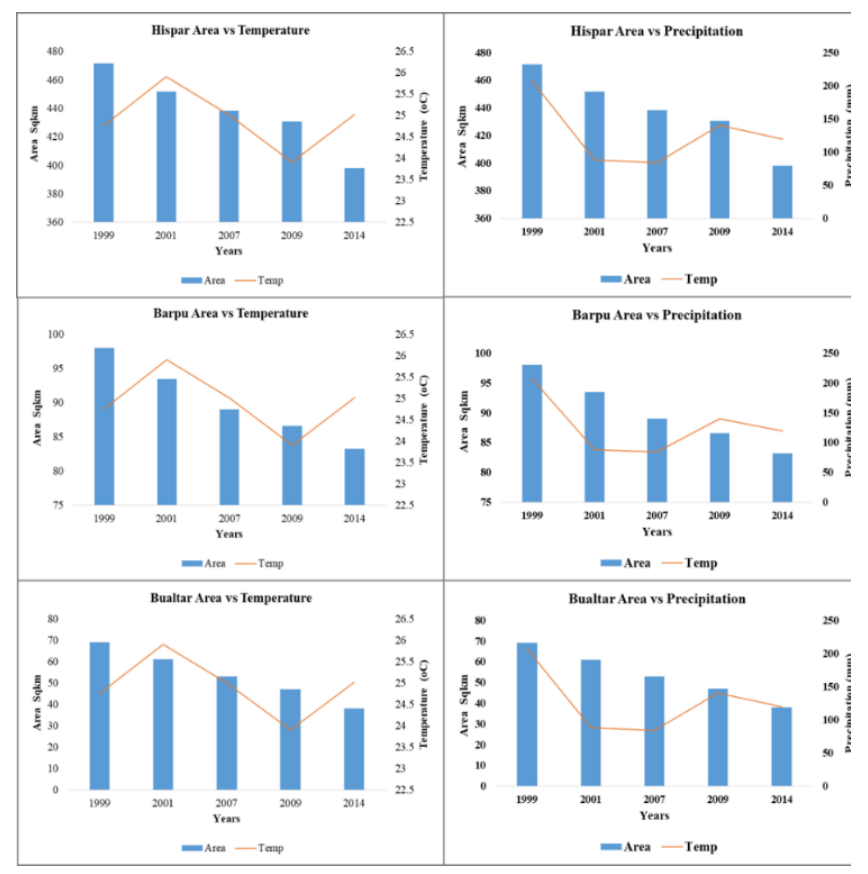

Figure 4: Influence of temperature and precipitation on glaciers dynamics

\section{CONCLUSIONS}

Glaciers are the major source of water resources in Pakistan. Therefore, melting of glaciers have strong socio-economic consequences for the country. Evaluating the temporal glacier inventories, shows that the selected glaciers are retreating with time, however, shows strong spatial and temporal variation. The temporal variation in the retreat rate is influenced by the supra glacier debris cover and climatic conditions. The clean glaciers in the region are at high risk than the debris covered glaciers. Glaciers mass balance data shall be collected to understand temporal trends and forecast the future climate of the region to help the relevant organizations for adaptation and mitigation measures.

\section{REFERENCES}

Ashraf, A., Naz, R., Rooh, R., 2012. Monitoring and estimation of glacial resource of Azad Jammu and Kashmir using remote sensing and GIS techniques. Pakistan Journal of Meteorology 816, 31-41.

Bajracharya, S.R., Maharjan, S.B., Shrestha, F., 2014. The status and decadal change of glaciers in Bhutan from the 1980s to 2010 based on satellite data. Annals of Glaciology 55, 159166.

Bhardwaj, A., Joshi, P.K., Snehmani, Sam, L., Singh, M.K., Singh, S., Kumar, R., 2015. Applicability of Landsat 8 data for characterizing glacier facies and supraglacial debris. International Journal of Applied Earth Observation and Geoinformation 38, 51-64.
Bocchiola, D., Diolaiuti, G., 2013. Recent (1980-2009) evidence of climate change in the upper Karakoram, Pakistan. Theoretical and applied climatology 113, 611-641.

Bolch, T., Menounos, B., Wheate, R., 2010. Landsat-based inventory of glaciers in western Canada, 1985-2005. Remote Sensing of Environment 114, 127-137.

Burns, P., Nolin, A., 2014. Using atmospherically-corrected Landsat imagery to measure glacier area change in the Cordillera Blanca, Peru from 1987 to 2010. Remote Sensing of Environment 140, 165-178.

Chaudhry, Q.-u.-Z., Mahmood, A., Rasul, G., Afzaal, M., 2009. Climate change indicators of Pakistan. Pakistan Meteorological Department, Islamabad. Technical Report No. PMD-22/2009, 1-43.

Dehecq, A., Gourmelen, N., Trouve, E., 2015. Deriving largescale glacier velocities from a complete satellite archive: Application to the Pamir-Karakoram-Himalaya. Remote Sensing of Environment 162, 55-66.

Durán-Alarcón, C., Gevaert, C.M., Mattar, C., JiménezMuñoz, J.C., Pasapera-Gonzales, J.J., Sobrino, J.A., SilviaVidal, Y., Fashé-Raymundo, O., Chavez-Espiritu, T.W., Santillan-Portilla, N., 2015. Recent trends on glacier area retreat over the group of Nevados Caullaraju-Pastoruri (Cordillera Blanca, Peru) using Landsat imagery. Journal of South American Earth Sciences 59, 19-26.

Gibson, M., Glasser, N., Quincey, D., Rowan, A., IrvineFynn, T., 2017. Changes in glacier surface cover on Baltoro glacier, Karakoram, north Pakistan, 2001-2012. Journal of Maps 13, 100-108.

Hall, D.K., Riggs, G.A., Salomonson, V.V., 1995. Development of methods for mapping global snow cover using moderate resolution imaging spectroradiometer data. Remote Sensing of Environment 54, 127-140.

Hewitt, K., 2005. The Karakoram anomaly? Glacier expansion and the'elevation effect,'Karakoram Himalaya. Mountain Research and Development 25, 332-340.

Kraaijenbrink, P., Shea, J., Pellicciotti, F., de Jong, S., Immerzeel, W., 2016a. Object-based analysis of unmanned aerial vehicle imagery to map and characterise surface features on a debris-covered glacier. Remote Sensing of Environment $186,581-595$.

Kraaijenbrink, P.D.A., Shea, J.M., Pellicciotti, F., Jong, S.M.d., Immerzeel, W.W., 2016b. Object-based analysis of unmanned aerial vehicle imagery to map and characterise surface features on a debris-covered glacier. Remote Sensing of Environment 186, 581-595.

Larsen, C.F., Motyka, R.J., Arendt, A.A., Echelmeyer, K.A., Geissler, P.E., 2007. Glacier changes in southeast Alaska and northwest British Columbia and contribution to sea level rise. Journal of Geophysical Research: Earth Surface 112, 1-11.

Li, G., Lin, H., 2017. Recent decadal glacier mass balances over the Western Nyainqentanglha Mountains and the increase in their melting contribution to Nam Co Lake measured by differential bistatic SAR interferometry. Global and Planetary Change 149, 177-190. 
López-Moreno, J.I., Fontaneda, S., Bazo, J., Revuelto, J., Azorin-Molina, C., Valero-Garcés, B., Morán-Tejeda, E., Vicente-Serrano, S.M., Zubieta, R., Alejo-Cochachín, J., 2014. Recent glacier retreat and climate trends in Cordillera Huaytapallana, Peru. Global and Planetary Change 112, 1-11. Muhammad, S., Tian, L., 2016. Changes in the ablation zones of glaciers in the western Himalaya and the Karakoram between 1972 and 2015. Remote Sensing of Environment 187, 505-512.

Paul, F., Barrand, N., Baumann, S., Berthier, E., Bolch, T., Casey, K., Frey, H., Joshi, S., Konovalov, V., Bris, R.L., 2013. On the accuracy of glacier outlines derived from remotesensing data. Annals of Glaciology 54, 171-182.

Paul, F., Huggel, C., Kääb, A., 2004a. Combining satellite multispectral image data and a digital elevation model for mapping debris-covered glaciers. Remote sensing of Environment 89, 510-518.

Paul, F., Kaab, A., Maisch, M., Kellenberger, T., Haeberli, W., 2004b. Rapid disintegration of Alpine glaciers observed with satellite data. Geophysical research letters 31 .

Qureshi, M.A., Yi, C., Xu, X., Li, Y., 2017. Glacier status during the period 1973-2014 in the Hunza Basin, Western Karakoram. Quaternary International.

Racoviteanu, A., Williams, M.W., 2012. Decision tree and texture analysis for mapping debris-covered glaciers in the Kangchenjunga area, eastern Himalaya. Remote Sensing 4, 3078-3109.

Racoviteanu, A.E., Williams, M.W., Barry, R.G., 2008. Optical Remote Sensing of Glacier Characteristics: A Review with Focus on the Himalaya. Sensors 8, 3355-3383.

Rankl, M., Kienholz, C., Braun, M., 2014. Glacier changes in the Karakoram region mapped by multimission satellite imagery. The Cryosphere 8, 977-989.

Schauwecker, S., Rohrer, M., Acuña, D., Cochachin, A., Dávila, L., Frey, H., Giráldez, C., Gómez, J., Huggel, C., Jacques-Coper, M., 2014. Climate trends and glacier retreat in the Cordillera Blanca, Peru, revisited. Global and planetary change 119, 85-97.

Scherler, D., Bookhagen, B., Strecker, M.R., 2011a. Spatially variable response of Himalayan glaciers to climate change affected by debris cover. Nature Geoscience 4, 56-59.

Scherler, D., Bookhagen, B., Strecker, M.R., 2011b. Spatially variable response of Himalayan glaciers to climate change affected by debris cover. Nature geoscience 4, 156-159.

Scherler, D., Leprince, S., Strecker, M.R., 2008. Glaciersurface velocities in alpine terrain from optical satellite imagery-Accuracy improvement and quality assessment. Remote Sensing of Environment 112, 3806-3819.

Sibandze, P., Mhangara, P., Odindi, J., Kganyago, M., 2014. A comparison of Normalised Difference Snow Index (NDSI) and Normalised Difference Principal Component Snow Index (NDPCSI) techniques in distinguishing snow from related land cover types. South African Journal of Geomatics 3, 197 209.
Tahir, A., Chevallier, P., Arnaud, Y., Ahmad, B., 2011. Snow cover dynamics and hydrological regime of the Hunza River basin, Karakoram Range, Northern Pakistan. Hydrol. Earth Syst. Sci 15, 2275-2290.

Williams, R.S., Ferrigno, J.G., Manley, W.F., 2010. Glaciers of Asia. US Government Printing Office.

Yao, T., Thompson, L., Yang, W., Yu, W., Gao, Y., Guo, X., Yang, X., Duan, K., Zhao, H., Xu, B., 2012. Different glacier status with atmospheric circulations in Tibetan Plateau and surroundings. Nature Climate Change 2, 663-667. 